\title{
Synthesis and Fluorescence Properties of a Structurally Characterized Hetero-Hexanuclear Zn(II)-La(III) Salamo-Like Coordination Compound Containing Auxiliary Ligands
}

\author{
Wen-Ting Guo ${ }^{1,2}$, Ling-Zhi Liu ${ }^{1}$, Meng Yu ${ }^{1}$, Fei Wang ${ }^{1}$, Jian-Chun Ma ${ }^{1}$ and \\ Wen-Kui Dong $1, *$ (D) \\ 1 School of Chemical and Biological Engineering, Lanzhou Jiaotong University, Lanzhou 730070, China; \\ gwtzy044@126.com (W.-T.G.); 1lz1009663202@126.com (L.-Z.L.); 18347584353@163.com (M.Y.); \\ wangfei3986@163.com (F.W.); majc0204@126.com (J.-C.M.) \\ 2 Chemical Engineering Department, Jiuquan Vocational Technical College, Jiuquan 735000, China \\ * Correspondence: dongwk@mail.lzjtu.cn; Tel.: +86-931-493-8703
}

Received: 11 October 2018; Accepted: 1 November 2018; Published: 4 November 2018

\begin{abstract}
A hetero-hexanuclear $\mathrm{Zn}(\mathrm{II})-\mathrm{La}(\mathrm{III})$ coordination compound, $\left[\left\{(\mathrm{ZnL})_{2} \mathrm{La}\right\}_{2}(\mathrm{bdc})_{2}\right]\left(\mathrm{NO}_{3}\right)_{2}$ $\left(\mathrm{H}_{2}\right.$ bdc $=$ terephthalic acid $)$ has been synthesized with a symmetric Salamo-like bisoxime, and characterized by elemental analyses, IR, UV-Vis, fluorescent spectroscopy, and single-crystal $X$-ray diffraction analysis. All of the $\mathrm{Zn}(\mathrm{II})$ ions are pentacoordinated by $\mathrm{N}_{2} \mathrm{O}_{2}$ donator atoms from the $(\mathrm{L})^{2-}$ unit and one oxygen atom from one terephthalate anion. The $\mathrm{Zn}$ (II) ions adopt trigonal bipyramidal geometries $\left(\tau_{\mathrm{Zn} 1}=0.61, \tau_{\mathrm{Zn} 2}=0.56\right)$. The $\mathrm{La}(\mathrm{III})$ ions are decacoordinated in the $\mathrm{Zn}(\mathrm{II})-\mathrm{La}(\mathrm{III})$ coordination compound and has a distorted bicapped square antiprism geometry. Meanwhile, the photophysical property of the $\mathrm{Zn}(\mathrm{II})-\mathrm{La}(\mathrm{III})$ coordination compound was also measured and discussed.
\end{abstract}

Keywords: Salamo-like bisoxime; $\mathrm{Zn}(\mathrm{II})-\mathrm{La}(\mathrm{III})$ coordination compound; crystal structure; photophysical property

\section{Introduction}

Salen-like ( $N, N$-bis(salicylidene)ethylenediamine) $\mathrm{N}_{2} \mathrm{O}_{2}$ compounds are a class of the most versatile multidentate chelating ligands and could form stable mono- or multi-nuclear metal coordination compounds with alkaline earth, rare earth, and d-block transition metal ions [1-9]. Salen-like ligands and their corresponding metal coordination compounds have been proverbially studied in recent decades [10-16], these metal coordination compounds are used as precursors to obtain a great deal of oligometallic coordination compounds own to the high coordination abilities [17-21]. In recent years, our research mostly concentrated on the syntheses, crystal structures and properties of Salamo-like (1,2-bis(salicylideneaminooxy)ethane) derivatives and their metal coordination compounds. Salamo-like derivatives are at least $10^{4}$ times more stable than Salen-like ligands due to the unique structures of Salamo-like derivatives [22-24]. When 3-alkoxy groups are introduced of salicylidene moieties, the whole ligand molecule will have an $\mathrm{O}_{4}$ coordination site besides the $\mathrm{N}_{2} \mathrm{O}_{2}$ site. The $\mathrm{O}_{4}$ site of 3-alkoxy Salamo-like derivatives is suitable for alkali metals, alkaline earth metals and rare earth metal ions to obtain heteromulti-nuclear coordination compounds [25-28]. These hetero-metallic Salamo-like coordination compounds have been studied for their catalytic activities [29,30], biological activities [31], and fluorescence properties [32-34]. Meanwhile, supra-molecular chemistry has become increasingly prominent in the coordination 
chemistry, for Salamo-like derivatives, supra-molecular structures are formed mainly with the help of hydrogen bonding interactions [35-38]. In our previous studies, a number of Salamo-type derivatives and their hetero-nuclear coordination compounds have been synthesized [39-42]. However, 3d-4f hetero-nuclear Salamo-like coordination compounds containting auxiliary ligands have rarely been reported [43-45].

In order to explore the structures and optical properties of $3 \mathrm{~d}-4 \mathrm{f}$ hetero-nuclear metal coordination compounds contained auxiliary ligands, herein the terephtalic acid was selected as a simple multidentate linker owing to its availability and application in the building of Salamo-like Zn(II)-Ln(III) coordination compound. we have successfully designed and synthesized a symmetric Salamo-like derivative $\mathrm{H}_{2} \mathrm{~L}$ and its corresponding $\mathrm{Zn}$ (II)-La(III) coordination compound $\left(\left[\left\{(\mathrm{ZnL})_{2} \mathrm{La}\right\}_{2}(\mathrm{bdc})_{2}\right]\left(\mathrm{NO}_{3}\right)_{2}\right)$. Furthermore, the supra-molecular features and photophysical properties of the $\mathrm{Zn}(\mathrm{II})-\mathrm{La}(\mathrm{III})$ coordination compound are discussed in detail.

\section{Experimental}

\subsection{Materials and Instrumentation}

All chemical reagents were analytical pure reagents, which have not been purified before used. Carbon, nitrogen and hydrogen analyses were obtained using a GmbH VarioEL V3.00 automatic elemental analyzer (Berlin, Germany). Elemental analyses for $\mathrm{Zn}^{\mathrm{II}}$ and $\mathrm{La}^{\mathrm{III}}$ were detected by an IRIS ER/S-WP-1 ICP atomic emission spectrometer (Berlin, Germany). Melting points were measured via a microscopic melting point apparatus (Beijing Taike Instrument Limited Company, Beijing, China). ${ }^{1} \mathrm{H}$ and ${ }^{13} \mathrm{C}$ NMR spectra were recorded in deuterated DMSO solution by German Bruker AVANCE DRX-400 spectroscopy (Bruker AVANCE, Billerica, MA, USA). Infrared spectra were measured with a VERTEX-70 FT-IR spectrophotometer (Bruker, Billerica, MA, USA), with samples prepared as KBr $\left(400-4000 \mathrm{~cm}^{-1}\right)$. UV-Vis absorption and fluorescence spectra were recorded on a Shimadzu UV-2550 (Shimadzu, Japan) and Hitachi F-7000 (Hitachi, Tokyo, Japan) spectrometers, respectively. Quantum yields in solid state were measured using an absolute method by integrating sphere on FLS920 of Edinburgh Instrument. X-ray single crystal structure determination was carried out on a Bruker Smart Apex CCD diffractometer (Bruker AVANCE, Billerica, MA, USA).

\subsection{Preparation of Ligand $\mathrm{H}_{2} \mathrm{~L}$}

Preparation of 1,2-bis(aminooxy)ethane was in accordance with the literature [46,47]. Yield: $71.5 \%$. Anal. Calcd for $\mathrm{C}_{2} \mathrm{H}_{8} \mathrm{~N}_{2} \mathrm{O}_{2}$ (\%): C, 26.08; $\mathrm{H}, 8.76 ; \mathrm{N}, 30.42$. Found: $\mathrm{C}, 25.87 ; \mathrm{H}, 8.68 ; \mathrm{N}, 30.51 .{ }^{1} \mathrm{H} \mathrm{NMR}$ $\left(400 \mathrm{MHz}, \mathrm{CDCl}_{3}\right) \delta 3.79(\mathrm{~s}, 4 \mathrm{H}), 5.52(\mathrm{~s}, 4 \mathrm{H})$.

The ligand $\mathrm{H}_{2} \mathrm{~L}$ was synthesized according to the procedure reported early [43]. Reaction of 1,2-bis(aminooxy)ethane with two equivalents of 3-methoxysalicylaldehyde in ethanol afforded the desired ligand $\mathrm{H}_{2} \mathrm{~L}$. The synthesis routes of the Salamo-like bisoxime derivative $\left(\mathrm{H}_{2} \mathrm{~L}\right)$ and its $\mathrm{Zn}(\mathrm{II})-\mathrm{La}(\mathrm{III})$ coordination compound are shown in Scheme 1. Yield: $81.6 \%$. Mp: $132-134{ }^{\circ} \mathrm{C} .{ }^{1} \mathrm{H} \mathrm{NMR}$ $\left(400 \mathrm{MHz}, \mathrm{CDCl}_{3}\right) \delta 3.87(\mathrm{~s}, 6 \mathrm{H}), 4.46(\mathrm{~s}, 4 \mathrm{H}), 6.81(\mathrm{dd}, J=7.9,1.9 \mathrm{~Hz}, 2 \mathrm{H}), 6.86(\mathrm{t}, J=7.9 \mathrm{~Hz}, 2 \mathrm{H}), 6.95$ $(\mathrm{dd}, J=7.9,1.9 \mathrm{~Hz}, 2 \mathrm{H}), 8.23(\mathrm{~s}, 2 \mathrm{H}), 9.70(\mathrm{~s}, 2 \mathrm{H}) .{ }^{13} \mathrm{C} \mathrm{NMR}\left(100 \mathrm{MHz}, \mathrm{CDCl}_{3}\right) \delta 57.4\left(\mathrm{CH}_{3}\right), 72.8\left(\mathrm{CH}_{2}\right)$, $115.3(\mathrm{CH}), 119.2(\mathrm{C}), 119.6(\mathrm{CH}), 124.1(\mathrm{CH}), 149.5(\mathrm{C}), 150.2(\mathrm{C}), 152.7(\mathrm{CH}=\mathrm{N}) . \mathrm{IR}\left(\mathrm{KBr}, \mathrm{cm}^{-1}\right)$ : 3137 (m) $[v(\mathrm{O}-\mathrm{H})], 1601(\mathrm{~m})[v(\mathrm{C}=\mathrm{N})], 1255(\mathrm{~m})[v(\mathrm{Ar}-\mathrm{O})]$. Anal. Calcd for $\mathrm{C}_{18} \mathrm{H}_{20} \mathrm{~N}_{2} \mathrm{O}_{6}(\%): \mathrm{C}, 59.99 ; \mathrm{H}$, 5.59; N, 7.77. Found: C, 60.07; H, 5.73; N, 7.61\%. 

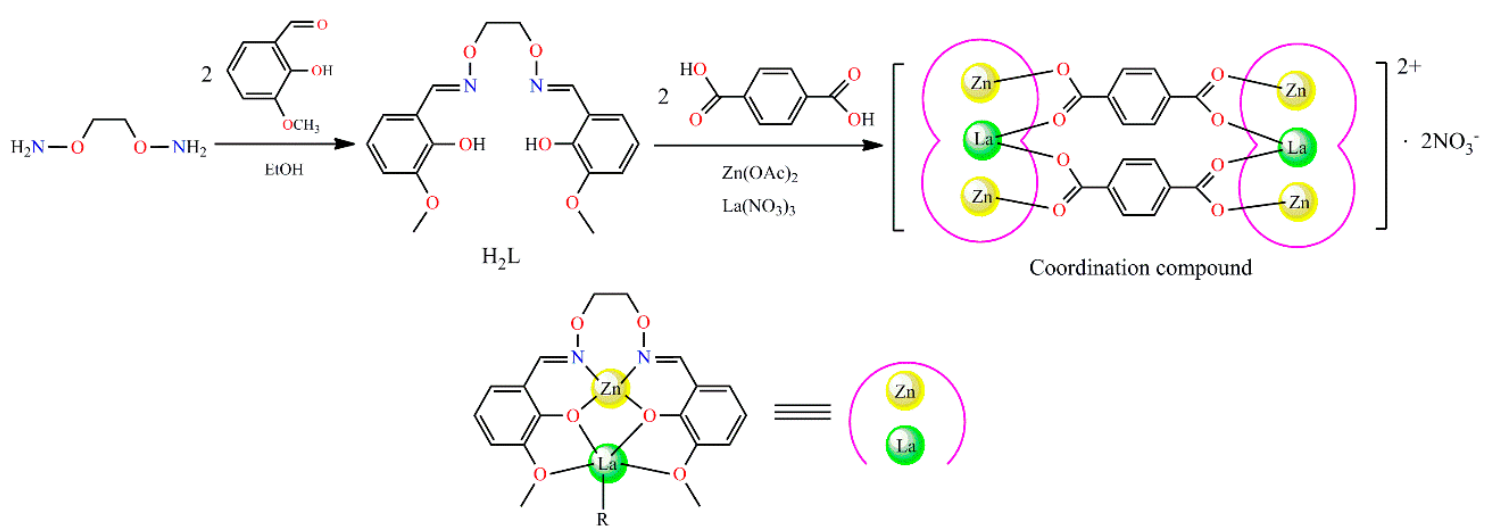

Scheme 1. Synthesis routes of the Salamo-like derivative $\mathrm{H}_{2} \mathrm{~L}$ and its $\mathrm{Zn}$ (II)-La(III) coordination compound.

\subsection{Preparation of the Zn(II)-La(III) Coordination Compound}

Synthesis route of the $\mathrm{Zn}(\mathrm{II})-\mathrm{La}(\mathrm{III})$ coordination compound is shown in Scheme 1. To stirring colorless transparent solution of $\mathrm{H}_{2} \mathrm{~L}(15.8 \mathrm{mg}, 0.02 \mathrm{mmol})$ in $\mathrm{CHCl}_{3}(3 \mathrm{~mL})$ was added $\mathrm{Zn}(\mathrm{OAc})_{2} \cdot 2 \mathrm{H}_{2} \mathrm{O}$ $(4.38 \mathrm{mg}, 0.02 \mathrm{mmol})$ and $\mathrm{La}\left(\mathrm{NO}_{3}\right)_{3} \cdot 6 \mathrm{H}_{2} \mathrm{O}(0.02 \mathrm{mmol})$ in $\mathrm{CH}_{3} \mathrm{OH}(2 \mathrm{~mL})$. The color of the mixture immediately turns pale yellow and then allowed to mixing with terephthalic acid $(0.01 \mathrm{mmol})$ in $\mathrm{CH}_{3} \mathrm{OH}(1 \mathrm{~mL})$ and continues stirring for about $30 \mathrm{~min}$ at room temperature. After the mixed solution was filtered by absorbent cotton, leaves the filtrate at room temperature for about two weeks. Finally, light-yellow and block-shaped crystals were obtained with the volatilization of solvent. Yield: $60.5 \%$. IR $\left(\mathrm{KBr}, \mathrm{cm}^{-1}\right): 1557(\mathrm{~m})[v(\mathrm{C}=\mathrm{N})], 1220(\mathrm{~m})[v(\mathrm{Ar}-\mathrm{O})], 449(\mathrm{~m})[v(\mathrm{Zn}-\mathrm{N})], 529(\mathrm{~m})$ [v(Zn-O)]. Anal. Calcd for $\mathrm{C}_{88} \mathrm{H}_{80} \mathrm{Zn}_{4} \mathrm{La}_{2} \mathrm{~N}_{10} \mathrm{O}_{38}$ (\%): C, 43.59; H, 3.33; N, 5.78; Zn, 10.78; La, 11.46. Found: C, 43.71; H, $2.98 ; \mathrm{N}, 5.46 ; \mathrm{Zn}, 10.84 ; \mathrm{La}, 11.39$.

\subsection{Structure Description of the Zn(II)-La(III) Coordination Compound}

Crystal data of the $\mathrm{Zn}(\mathrm{II})-\mathrm{La}(\mathrm{III})$ coordination compound were collected on a Bruker Smart Apex CCD diffractometer at $173(2) \mathrm{K}\left(\mathrm{Mo}-K_{\alpha}\right.$ radiation $\left.(\lambda=0.71073 \AA)\right)$. The LP factor and Semi-empirical absorption corrections were applied to the intensity data. The structure was solved by the direct methods and refined anisotropically using full-matrix least-squares methods on $\mathrm{F}^{2}$ with the SHELX-2018 program package. The hydrogen atoms were positioned geometrically and refined isotropically using the 'riding' model (SHELXL-2018). In addition, DELU and AFIX were applied in the structure refinement. The structure contained large in the void couldn't be identified because it was highly disordered and had so small residual peak. Therefore, SQUEEZE in PLATON program was performed to remove the highly disordered solvent. (Solvent Accessible Volume $=914$, Electrons Found in S.A.V. $=484)$. The nonhydrogen atoms were refined anisotropically. Crystal data and structure parameters for the $\mathrm{Zn}(\mathrm{II})-\mathrm{La}$ (III) coordination compound are given in Table 1. Supplementary crystallographic data for this paper have been deposited at Cambridge Crystallographic Data Centre (1434632) and can be obtained free of charge via www.ccdc.cam.ac.uk/conts/retrieving.html.

Table 1. Crystal data and structure parameters for the $\mathrm{Zn}(\mathrm{II})-\mathrm{La}(\mathrm{III})$ coordination compound.

\begin{tabular}{cc}
\hline Coordination Compound & $\mathrm{Zn}(\mathrm{II})$-La(III) \\
\hline Empirical formula & $\mathrm{C}_{88} \mathrm{H}_{80} \mathrm{Zn}_{4} \mathrm{La}_{2} \mathrm{~N}_{10} \mathrm{O}_{38}$ \\
Molecular weight, $\mathrm{g} \cdot \mathrm{mol}^{-1}$ & 2424.92 \\
Color & Yellow \\
Crystal size, $\mathrm{mm}^{3}$ & $0.15 \times 0.12 \times 0.06$ \\
Habit & Block-shaped \\
Crystal system & Triclinic \\
Space group & $P-1$ \\
\hline
\end{tabular}


Table 1. Cont.

\begin{tabular}{cc}
\hline Coordination Compound & Zn(II)-La(III) \\
\hline Unit cell dimension & \\
$b(\AA)$ & $12.5918(11)$ \\
$c(\AA)$ & $15.9312(15)$ \\
$\alpha\left(^{\circ}\right)$ & $16.1881(17)$ \\
$\beta\left(^{\circ}\right)$ & $68.980(12)$ \\
$\gamma\left({ }^{\circ}\right)$ & $84.083(8)$ \\
$V\left(\AA^{3}\right)$ & $86.619(9)$ \\
$Z$ & $3014.3(6)$ \\
$Z^{\prime}$ & 1 \\
$D_{\mathrm{c}}\left(\mathrm{g}^{\circ} \mathrm{cm}^{-3}\right)$ & 0.5 \\
$\mu\left(\mathrm{mm}^{-1}\right)$ & 1.336 \\
$F(000)$ & 1.550 \\
$\theta$ Range $\left({ }^{\circ}\right)$ & 1216 \\
Index ranges & $1.353-26.022$ \\
Reflections collected & $118 \leq k \leq 19,0 \leq l \leq 19$ \\
Completeness $(\%)$ & 99.4 \\
Data/restraints/parameters & $11812 / 11 / 644$ \\
Final $R_{1} / w R_{2}[I>2 \sigma(I)]$ & $R_{1}=0.0397, w R_{2}=0.1053$ \\
Final $R_{1} / w R_{2}($ all data) & 0.715 and -0.626 \\
$\Delta \rho_{\text {max }} /$ min $\left(\mathrm{e}^{-3} \AA^{-3}\right)$ &
\end{tabular}

\section{Results and Discussion}

\subsection{Infrared Spectra}

The infrared spectra of $\mathrm{H}_{2} \mathrm{~L}$ and its $\mathrm{Zn}(\mathrm{II})-\mathrm{La}(\mathrm{III})$ coordination compound exhibited various bands in the $400-4000 \mathrm{~cm}^{-1}$ range (Figure 1). The free ligand $\mathrm{H}_{2} \mathrm{~L}$ exhibited an obvious characteristic band at $3137 \mathrm{~cm}^{-1}$ and can be attributed to the characteristic bands of the $\mathrm{OH}$ group. This band was dispeared in the infrared spectrum of the $\mathrm{Zn}(\mathrm{II})-\mathrm{La}(\mathrm{III})$ coordination compound, indicating the interaction between the $\mathrm{OH}$ group and the $\mathrm{Zn}$ (II) ion leads to hydroxyl deprotonation [34]. In addition, the free ligand $\mathrm{H}_{2} \mathrm{~L}$ showed an individual $\mathrm{C}=\mathrm{N}$ stretching band at $1601 \mathrm{~cm}^{-1}$, while the $\mathrm{C}=\mathrm{N}$ stretching band of the $\mathrm{Zn}$ (II)-La(III) coordination compound appeared at $1557 \mathrm{~cm}^{-1}$. For the ligand $\mathrm{H}_{2} \mathrm{~L}$, the Ar-O stretching band appeared at $1255 \mathrm{~cm}^{-1}$, which was observed at $1220 \mathrm{~cm}^{-1}$ for the $\mathrm{Zn}(\mathrm{II})-\mathrm{La}(\mathrm{III})$ coordination compound. The vibration of $\mathrm{NO}_{3}{ }^{-}$anion appeared at about $1459 \mathrm{~cm}^{-1}$ in the spectrum of the $\mathrm{Zn}(\mathrm{II})-\mathrm{La}(\mathrm{III})$ coordination compound. The $\mathrm{C}=\mathrm{N}$ and $\mathrm{Ar}-\mathrm{O}$ stretching frequencies are shifted, indicating the formation of new chemical bonds ( $\mathrm{Zn}-\mathrm{O}$ and $\mathrm{Zn}-\mathrm{N}$ ) [25]. For the $\mathrm{Zn}$ (II)-La(III) coordination compound, the $v(\mathrm{Zn}-\mathrm{O})$ and $v(\mathrm{Zn}-\mathrm{N})$ frequencies were observed at 449 and $529 \mathrm{~cm}^{-1}$, respectively. Just as Percy and Thornton suggested [48], the M-O and M-N stretching frequency assignments are difficult sometimes.

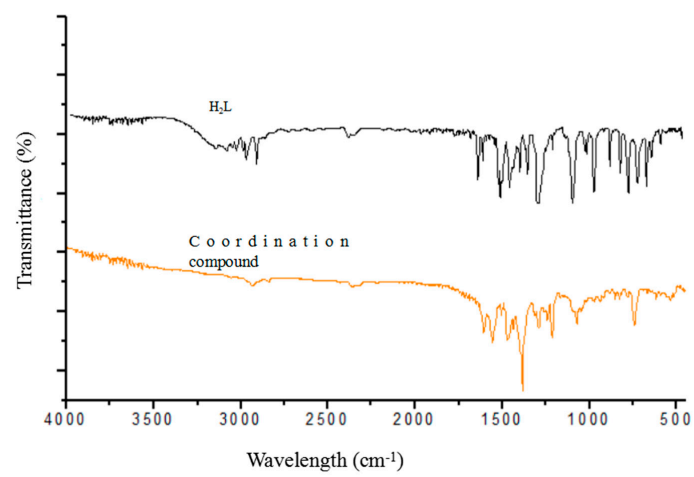

Figure 1. The infrared spectra of the ligand $\mathrm{H}_{2} \mathrm{~L}$ and its $\mathrm{Zn}(\mathrm{II})-\mathrm{La}(\mathrm{III})$ coordination compound. 


\subsection{UV-Vis Spectra}

The UV-Vis spectra of $\mathrm{H}_{2} \mathrm{~L}$ and its $\mathrm{Zn}(\mathrm{II})-\mathrm{La}(\mathrm{III})$ coordination compound were measured in $1 \times 10^{-5} \mathrm{~mol} \cdot \mathrm{L}^{-1} \mathrm{CH}_{2} \mathrm{Cl}_{2}$ solution in freshly prepared solution are obtained in the range of $200-450 \mathrm{~nm}$ at room temperature, as shown in Figure 2. As can be seen from the diagram, the absorption peak of the $\mathrm{Zn}$ (II)-La(III) coordination compound is evidently different from the ligand before coordination. The absorption spectrum of $\mathrm{H}_{2} \mathrm{~L}$ showed that two relatively strong absorption peaks appeared at ca. $266 \mathrm{~nm}\left(\varepsilon=1.8 \times 10^{4} \mathrm{M}^{-1} \cdot \mathrm{cm}^{-1}\right)$ and $322 \mathrm{~nm}\left(\varepsilon=6.1 \times 10^{3} \mathrm{M}^{-1} \cdot \mathrm{cm}^{-1}\right)$, which can be attributed to $\pi-\pi^{*}$ transitions of the benzene rings and the $\mathrm{C}=\mathrm{N}$ bonds [17]. Compared with the free ligand $\mathrm{H}_{2} \mathrm{~L}$, the corresponding absorption peak of the $\mathrm{Zn}$ (II)-La(III) coordination compound appeared at ca. $278 \mathrm{~nm}$ $\left(\varepsilon=4.1 \times 10^{4} \mathrm{M}^{-1} \cdot \mathrm{cm}^{-1}\right)$ was remarkably red shifted upon coordination to metal ions. The absorption peak at ca. $322 \mathrm{~nm}$ is absent in the $\mathrm{Zn}$ (II)-La(III) coordination compound. Meanwhile, a new absorption peak appeared at ca. $349 \mathrm{~nm}\left(\varepsilon=1.2 \times 10^{4} \mathrm{M}^{-1} \cdot \mathrm{cm}^{-1}\right)$ in the $\mathrm{Zn}$ (II)-La(III) coordination compound that might be owing to $\mathrm{M} \rightarrow \mathrm{L}$ (MLCT) charge-transfer transition, which is characteristic of the transition metal coordination compound with $\mathrm{N}_{2} \mathrm{O}_{2}$ coordination spheres [27].

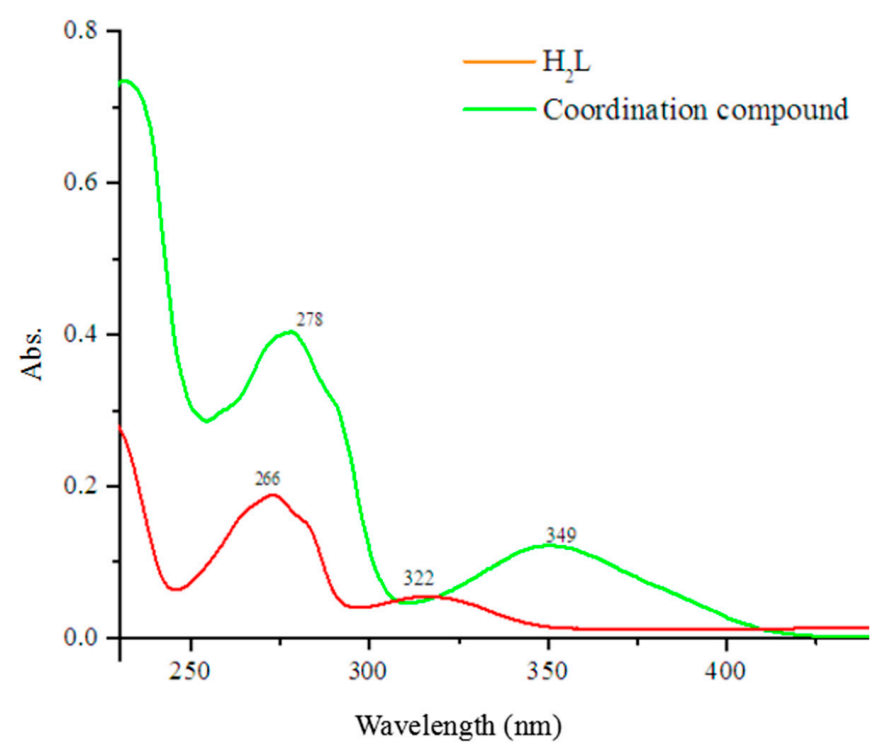

Figure 2. UV-Vis spectra of $\mathrm{H}_{2} \mathrm{~L}$ and its $\mathrm{Zn}(\mathrm{II})-\mathrm{La}(\mathrm{III})$ coordination compound.

\subsection{Crystal Structure of Zn(II)-La(III) Coordination Compound}

Crystal structure of the $\mathrm{Zn}(\mathrm{II})-\mathrm{La}(\mathrm{III})$ coordination compound exhibited a symmetric hexanuclear structure, which is different from the common trinuclear bis(salamo)-type coordination compounds reported earlier [43,46]. The crystal structure of the $\mathrm{Zn}(\mathrm{II})-\mathrm{La}(\mathrm{III})$ coordination compound and the coordination polyhedra of metal atoms are shown in Figure 3. Essential bond lengths and angles are listed in Table 2.

Table 2. Essential bond lengths $(\AA)$ and angles $\left(^{\circ}\right)$ for the $\mathrm{Zn}(\mathrm{II})-\mathrm{La}(\mathrm{III})$ coordination compound.

\begin{tabular}{cccccc}
\hline Bond & \multicolumn{3}{c}{ Bond } & \multicolumn{3}{c}{ Bond } \\
\hline La1-O13 & $2.459(3)$ & La1-O1 & $2.720(3)$ & O14-Zn1 & $1.998(3)$ \\
La1-O16 & $2.497(3)$ & La1-O12 & $2.781(3)$ & O5-Zn1 & $2.055(3)$ \\
La1-O8 & $2.506(2)$ & La1-O6 & $2.813(3)$ & N4-Zn2 & $1.992(4)$ \\
La1-O5 & $2.519(3)$ & La1-Zn1 & $3.5369(7)$ & N3-Zn2 & $2.122(3)$ \\
La1-O11 & $2.523(3)$ & La1-Zn2 & $3.5491(7)$ & O8-Zn2 & $1.976(3)$ \\
La1-O2 & $2.536(3)$ & N1-Zn1 & $2.132(3)$ & O11-Zn2 & $2.065(3)$ \\
La1-O7 & $2.690(3)$ & N2-Zn1 & $2.034(4)$ & O15-Zn2 ${ }^{\# 1}$ & $1.984(3)$ \\
\hline
\end{tabular}


Table 2. Cont.

\begin{tabular}{|c|c|c|c|c|c|}
\hline Bond & & Bond & & Bond & \\
\hline Angles & & Angles & & Angles & \\
\hline O13-La1-O16 & $75.54(9)$ & O5-La1-O2 & $62.63(9)$ & O12-La1-O6 & $161.99(9)$ \\
\hline O13-La1-O8 & $152.43(9)$ & O11-La1-O2 & $118.54(9)$ & O2-Zn1-O14 & $113.20(13)$ \\
\hline O16 ${ }^{\# 1-L a 1-O 8}$ & 76.91(9) & O13-La1-O7 & $139.64(9)$ & O2-Zn1-N2 & $126.73(13)$ \\
\hline O13-La1-O5 & $70.42(9)$ & O16 ${ }^{\# 1-L a 1-O 7}$ & $123.92(9)$ & O14-Zn1-N2 & $119.87(14)$ \\
\hline O16 \#1_La1-O5 & $107.80(9)$ & O8-La1-O7 & $59.53(9)$ & O2-Zn1-O5 & 81.13(11) \\
\hline O8-La1-O5 & $118.12(9)$ & O5-La1-O7 & $69.87(9)$ & O14-Zn1-O5 & $99.14(11)$ \\
\hline O13-La1-O11 & $108.48(9)$ & O11-La1-O7 & $111.38(9)$ & N2-Zn1-O5 & 86.31(13) \\
\hline O16 \#1_La1-O11 & $70.54(9)$ & O2-La1-O7 & $81.02(8)$ & O2-Zn1-N1 & $86.92(13)$ \\
\hline O8-La1-O11 & $62.21(9)$ & O13-La1-O1 & $122.61(9)$ & O14-Zn1-N1 & $96.36(12)$ \\
\hline O5-La1-O11 & $178.28(9)$ & O16 \#1-La1-O1 & $142.29(9)$ & N2-Zn1-N1 & $91.52(14)$ \\
\hline O13-La1-O2 & $74.77(9)$ & O8-La1-O1 & $80.96(8)$ & O5-Zn1-N1 & $163.23(12)$ \\
\hline $\mathrm{O} 16^{\# 1-\mathrm{La} 1-\mathrm{O} 2}$ & $150.28(9)$ & O5-La1-O1 & $109.50(9)$ & $\mathrm{O} 8-\mathrm{Zn} 2-\mathrm{O} 15^{\# 1}$ & 112.61(12) \\
\hline O8-La1-O2 & $132.80(9)$ & O11-La1-O1 & $72.20(9)$ & O8-Zn2-N4 & $130.16(15)$ \\
\hline O7-La1-O1 & $66.05(9)$ & O2-La1-O1 & $58.53(9)$ & $\mathrm{O} 15^{\# 1-Z n 2-N 4}$ & $116.62(15)$ \\
\hline O11-La1-O12 & $58.19(8)$ & O13-La1-O12 & $67.16(10)$ & O8-Zn2-O11 & $79.99(11)$ \\
\hline O2-La1-O12 & $69.32(9)$ & O16"\#1-La1-O12 & $97.93(9)$ & O15 \#1_Zn2-O11 & $97.48(11)$ \\
\hline O7-La1-O12 & 132.07(9) & O8-La1-O12 & $117.95(9)$ & N4-Zn2-O11 & $86.41(14)$ \\
\hline O1-La1-O12 & $66.44(9)$ & O5-La1-O12 & $121.99(8)$ & $\mathrm{O} 8-\mathrm{Zn} 2-\mathrm{N} 3$ & $87.90(14)$ \\
\hline O13-La1-O6 & $97.96(9)$ & O7-La1-O6 & $65.84(8)$ & $\mathrm{O} 15^{\# 1-Z n 2-N 3}$ & $97.41(12)$ \\
\hline O16 ${ }^{\# 1-L a 1-O 6}$ & $67.47(9)$ & O1-La1-O6 & $131.57(8)$ & N4-Zn2-N3 & $93.10(15)$ \\
\hline O8-La1-O6 & $70.46(9)$ & O11-La1-O6 & $121.87(8)$ & $\mathrm{O} 11-\mathrm{Zn} 2-\mathrm{N} 3$ & $163.57(13)$ \\
\hline O5-La1-O6 & $57.34(8)$ & O2-La1-O6 & $118.01(9)$ & & \\
\hline
\end{tabular}

Symmetry transformations used to generate equivalent atoms: ${ }^{\# 1}-x+2,-y+1,-z$.

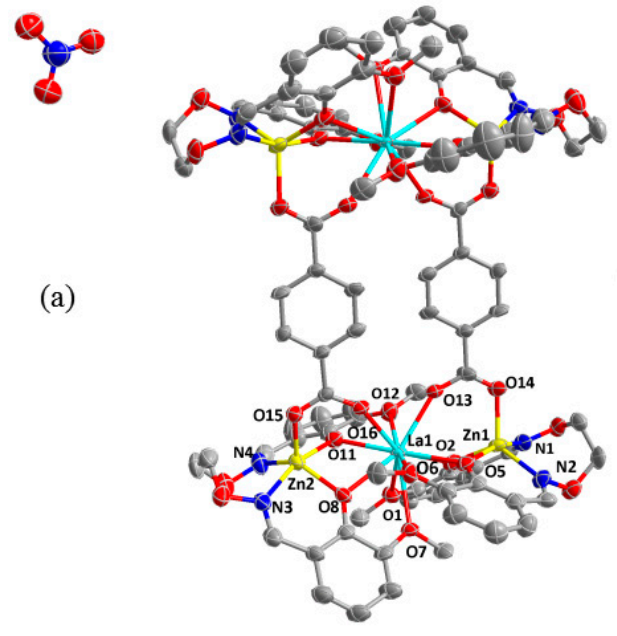

(b)
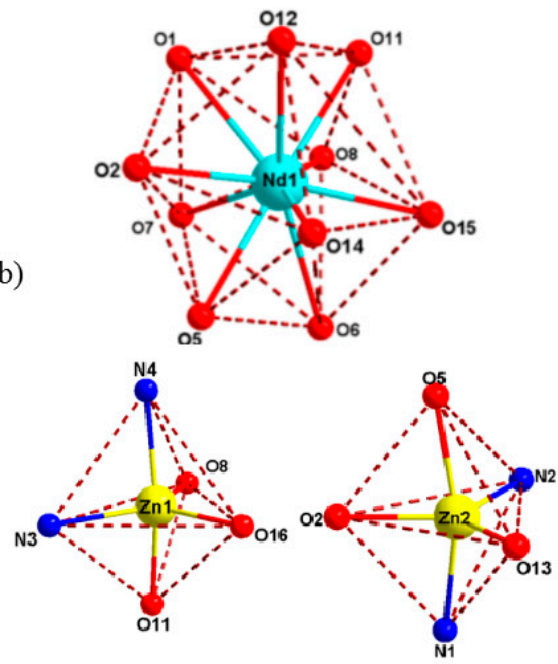

Figure 3. (a) Crystal structure of the $\mathrm{Zn}(\mathrm{II})$-La(III) coordination compound (hydrogen atoms are omitted in structure). (b) Coordination polyhedra for metal atoms of the $\mathrm{Zn}$ (II)-La(III) coordination compound.

The $\mathrm{Zn}(\mathrm{II})-\mathrm{La}(\mathrm{III})$ coordination compound crystallizes in the triclinic crystal system, space group $P-1$ and the unit cell contains four $\mathrm{Zn}(\mathrm{II})$ ions, four $(\mathrm{L})^{2-}$ units, two (bdc) ${ }^{2-}$ ions, two $\mathrm{La}(\mathrm{III})$ ions, and two free $\mathrm{NO}_{3}{ }^{-}$ions. The $\mathrm{Zn}(\mathrm{II})-\mathrm{La}$ (III) coordination compound was assembled by two trinuclear units $\left[(\mathrm{ZnL})_{2} \mathrm{La}\right]$ and two terephthalic acid, similar to the $\mathrm{Zn}(\mathrm{II})-\mathrm{Ln}(\mathrm{III})$ coordination compounds reported [49].

In the crystal structure of the $\mathrm{Zn}$ (II)-La(III) coordination compound, each $\mathrm{Zn}$ (II) ion is located in the $\mathrm{N}_{2} \mathrm{O}_{2}$ coordination cavity, which have pentacoordinate environments, and the axial position is occupied by one oxygen atom of terephthalic acid. The four $\mathrm{Zn}$ (II) ions assumes a distorted trigonal 
bipyramidal geometries, which were inferred by calculating the value of $\tau_{\mathrm{Zn} 1}=0.61, \tau_{\mathrm{Zn} 2}=0.56$, respectively [50]. The $\mathrm{La}(\mathrm{III})$ ions have a decacoordinate environment, consisting of eight oxygen atoms $(\mathrm{O} 1, \mathrm{O} 2, \mathrm{O} 5, \mathrm{O} 6, \mathrm{O} 7, \mathrm{O} 8, \mathrm{O} 11$, and $\mathrm{O} 12)$ come from two deprotonation $(\mathrm{L})^{2-}$ units, two oxygen atoms (O13 and $\mathrm{O} 16)$ of two terephthalic acid. Thus, all of the $\mathrm{La}(\mathrm{III})$ ions adopt a distorted bicapped square antiprism geometry.

The hydrogen bonding interactions are listed in Table 3. In the crystal structure of the $\mathrm{Zn}(\mathrm{II})-\mathrm{La}(\mathrm{III})$ coordination compound, the molecular structure is stabilized through intramolecular $\mathrm{C}-\mathrm{H} \cdots \mathrm{O}$

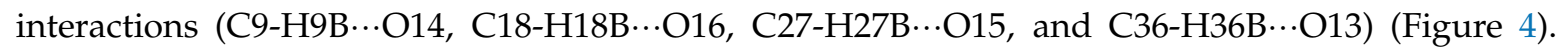
Intermolecular interactions, especially classical and non-classical hydrogen bonds, are playing a crucial role in the formation of crystalline solids and their physiochemical properties [51-59]. There are two inter-molecular $\mathrm{C} 29-\mathrm{H} 29 \cdots \mathrm{O} 10^{\#}$ and $\mathrm{C} 31-\mathrm{H} 31 \cdots \mathrm{O} 18$ hydrogen bonding interactions, which can link each cell unit through inter-molecular hydrogen bondings (Figure 5). Additionally, the hydrogen bonding scheme of the $\mathrm{Zn}$ (II)-La(III) coordination compound is defective owing to suppression of the electron density originating from solvent molecules (used SQUEEZE) and subsequent exclusion of these solvent molecules from the refinement model.

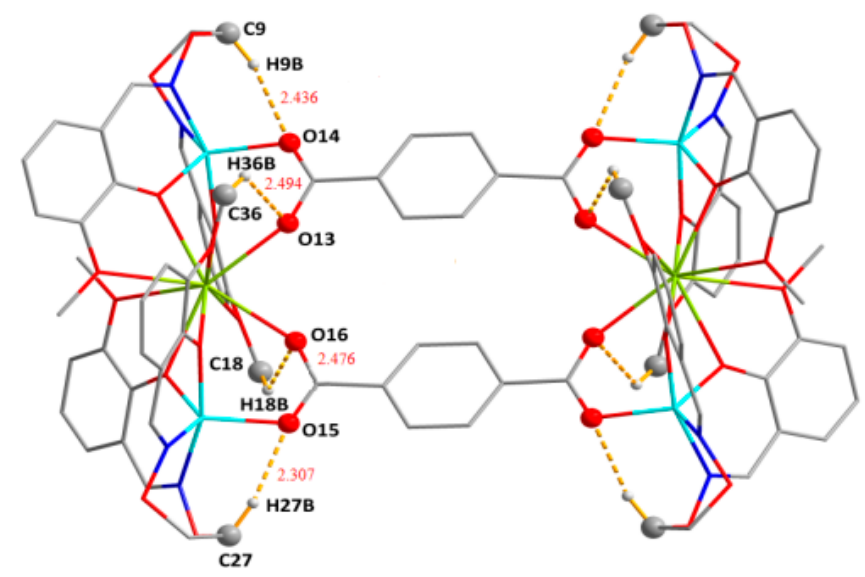

Figure 4. Intramolecular hydrogen bonding interactions of the $\mathrm{Zn}(\mathrm{II})-\mathrm{La}(\mathrm{III})$ coordination compound (hydrogen atoms, except those forming hydrogen bonds, are omitted for clarity).

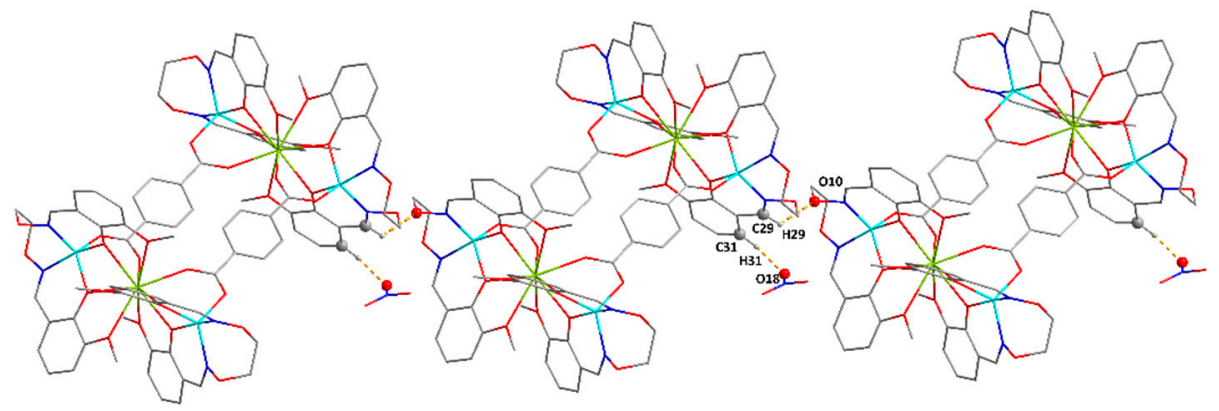

Figure 5. The one-dimensional structure of the $\mathrm{Zn}$ (II)-La(III) coordination compound with intermolecular hydrogen bondings (hydrogen atoms have been omitted except those formation of hydrogen bonds).

Table 3. Putative hydrogen bonding interactions $\left(\AA^{\mathrm{A}},^{\circ}\right)$ for the $\mathrm{Zn}(\mathrm{II})-\mathrm{La}(\mathrm{III})$ coordination compound.

\begin{tabular}{|c|c|c|c|c|c|}
\hline $\mathrm{D}-\mathrm{X} \cdots \mathrm{A}$ & $d(D-X)$ & $d(X \cdots A)$ & $\mathrm{d}(\mathrm{D} \cdots \mathrm{A})$ & $\angle \mathrm{DXA}$ & Symmetry Code \\
\hline 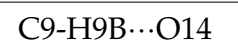 & 0.99 & 2.44 & $3.322(5)$ & 149 & \\
\hline 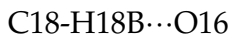 & 0.98 & 2.48 & $3.098(5)$ & 121 & \\
\hline C27-H27B $\cdots \mathrm{O} 15$ & 0.99 & 2.31 & $3.239(6)$ & 156 & \\
\hline C29-H29...O10 & 0.95 & 2.40 & $3.011(7)$ & 122 & $1-x, 2-y,-z$ \\
\hline 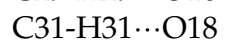 & 0.95 & 1.81 & $2.748(8)$ & 169 & $x, 1+y,-1+z$ \\
\hline С $36-\mathrm{H} 36 \mathrm{~B} \cdots \mathrm{O} 13$ & 0.98 & 2.49 & $3.122(6)$ & 122 & \\
\hline
\end{tabular}




\subsection{Fluorescence Properties}

The fluorescence properties of $\mathrm{H}_{2} \mathrm{~L}$ and its $\mathrm{Zn}(\mathrm{II})-\mathrm{La}(\mathrm{III})$ coordination compound were researched at room temperature (Figure 6).

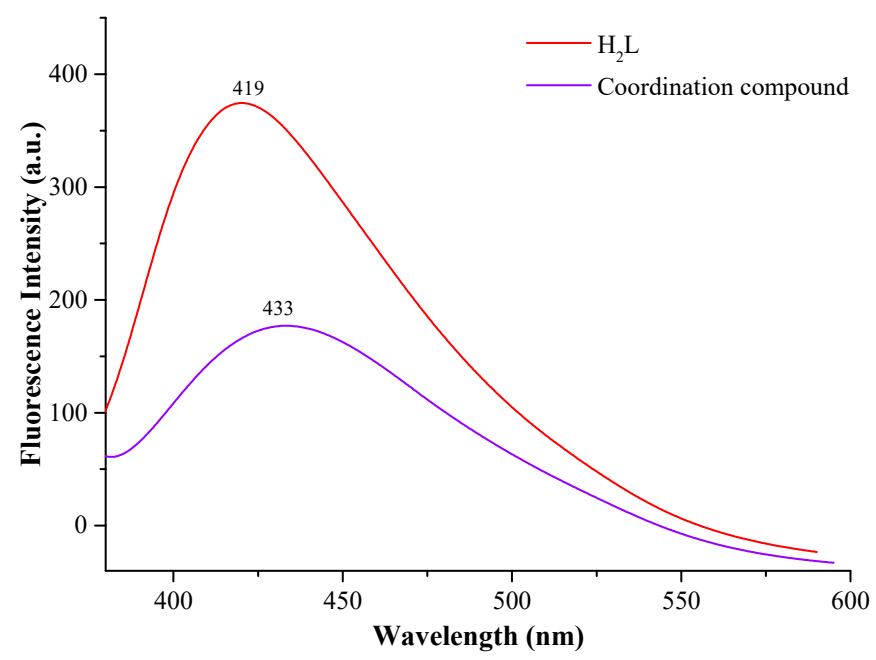

Figure 6. Emission spectra of $\mathrm{H}_{2} \mathrm{~L}\left(\mathrm{c}=1 \times 10^{-5} \mathrm{M}, \lambda_{\mathrm{ex}}=360 \mathrm{~nm}\right)$ and its $\mathrm{Zn}$ (II)-La(III) coordination compound.

With excitation at $360 \mathrm{~nm}$, the free ligand $\mathrm{H}_{2} \mathrm{~L}$ showed strong emission peak at about $419 \mathrm{~nm}$, which can be attributed to the intra-ligand $\pi-\pi^{*}$ transition. Similarly, the $\mathrm{Zn}$ (II)-La(III) coordination compound also exhibited an intense luminescence with maximum emission at ca. $433 \mathrm{~nm}$ and the emission quantum yield $\Phi=0.19 \%$ [49]. Compared with the ligand $\mathrm{H}_{2} \mathrm{~L}$, the fluorescence intensity of the $\mathrm{Zn}$ (II)-La(III) coordination compound showed a marked reduction, indicating that the addition of metal ions induced the change of fluorescence characteristics of the ligand; it is further explained that the $(\mathrm{Zn} / \mathrm{L})$-center has absorbed and transferred energy to $\mathrm{La}(\mathrm{III})$ ion as a type of metal-organic antenna [43].

\section{Conclusions}

We have designed and synthesized a symmetric Salamo-like bioxime ligand $\mathrm{H}_{2} \mathrm{~L}$, and obtained a hetero-hexanuclear $\mathrm{Zn}(\mathrm{II})-\mathrm{La}(\mathrm{III})$ coordination compound $\left[\left\{(\mathrm{ZnL})_{2} \mathrm{La}\right\}_{2}(\mathrm{bdc})_{2}\right]\left(\mathrm{NO}_{3}\right)_{2}$. The crystal structure of the $\mathrm{Zn}$ (II)-La(III) coordination compound showed that all of the $\mathrm{Zn}$ (II) ions have pentacoordinate environments and adopt distorted trigonal bipyramidal geometries. The La(III) ions adopt a distorted bicapped square antiprism geometry. The fluorescence behavior of $\mathrm{H}_{2} \mathrm{~L}$ and its $\mathrm{Zn}$ (II)-La(III) coordination compounds was studied, compared with the ligand $\mathrm{H}_{2} \mathrm{~L}$, the fluorescence intensity of the $\mathrm{Zn}(\mathrm{II})-\mathrm{La}(\mathrm{III})$ coordination compound showed a marked reduction, indicating that the addition of $\mathrm{Zn}(\mathrm{II})-\mathrm{La}(\mathrm{III})$ ions induced the change of fluorescence characteristics.

Author Contributions: W.-K.D. conceived and designed the experiments; W.-T.G. and J.-C.M. performed the experiments; F.W. and Y.Z. analyzed the data; L.-Z.L. and M.Y. wrote the paper. W.-K.D. contributed reagents/materials/analysis tools.

Funding: This research were funded by the National Natural Science Foundation of China (21761018) and the Program for Excellent Team of Scientific Research in Lanzhou Jiaotong University (201706).

Acknowledgments: This work was supported by the National Natural Science Foundation of China (21761018) and the Program for Excellent Team of Scientific Research in Lanzhou Jiaotong University (201706), which is gratefully acknowledged.

Conflicts of Interest: The authors declare no competing financial interests. 


\section{References}

1. Zhou, J.J.; Song, X.Q.; Liu, Y.A.; Wang, X.L. Substituent-tuned structure and luminescence sensitizing towards $\mathrm{Al}^{3+}$ based on phenoxy bridged dinuclear Eu ${ }^{\mathrm{III}}$ complexes. RSC Adv. 2017, 7, 25549-25559. [CrossRef]

2. Akine, S. Novel ion recognition systems based on cyclic and acyclic oligo(salen)-type ligands. J. Incl. Phenom. Macrocycl. Chem. 2012, 72, 25-54. [CrossRef]

3. Akine, S.; Varadi, Z.; Nabeshima, T. Synthesis of planar metal complexes and the ctacking abilities of naphthalenediol-based acyclic and macrocyclic Salen-type ligands. Eur. J. Inorg. Chem. 2013, 5987-5998. [CrossRef]

4. Che, C.M.; Huang, J.S. Metal complexes of chiral binaphthyl Schiff-base ligands and their application in stereoselective organic transformations. Coord. Chem. Rev. 2003, 242, 97-113. [CrossRef]

5. Song, X.Q.; Cheng, G.Q.; Wang, X.R.; Xu, W.Y.; Liu, P.P. Structure-based description of a step-by-step synthesis of heterodinuclear $\mathrm{Zn}^{\mathrm{II}} \mathrm{Ln}^{\mathrm{III}}$ complexes and their luminescence properties. Inorg. Chim. Acta 2015, 425, 145-153. [CrossRef]

6. Chai, L.Q.; Huang, J.J.; Zhang, H.S. An unexpected cobalt (III) complex containing a schiff base ligand: Synthesis, crystal structure, spectroscopic behavior, electrochemical property and SOD-like activity. Spectrochim. Acta Part A 2014, 131, 526-530. [CrossRef] [PubMed]

7. Chai, L.Q.; Huang, J.J.; Zhang, J.Y.; Li, Y.X. Two 1-D and 2-D cobalt(II) complexes: Synthesis, crystal structures, spectroscopic and electrochemical properties. J. Coord. Chem. 2015, 68, 1224-1237. [CrossRef]

8. Chai, L.Q.; Tang, L.J.; Chen, L.C.; Huang, J.J. Structural, spectral, electrochemical and DFT studies of two mononuclear manganese(II) and zinc(II) complexes. Polyhedron 2017, 122, 228-240. [CrossRef]

9. Chai, L.Q.; Zhang, K.Y.; Tang, L.J.; Zhang, J.Y.; Zhang, H.S. Two mono- and dinuclear Ni(II) complexes constructed from quinazoline-type ligands: Synthesis, x-ray structures, spectroscopic, electrochemical, thermal, and antimicrobial studies. Polyhedron 2017, 130, 100-107. [CrossRef]

10. Chen, C.Y.; Zhang, J.W.; Zhang, Y.H.; Yang, Z.H.; Wu, H.L. Gadolinium(III) and dysprosium(III) complexes with a schiff base bis( $N$-salicylidene)-3-oxapentane-1,5-diamine: Synthesis, characterization, antioxidation, and DNA-binding studies. J. Coord. Chem. 2015, 68, 1054-1071. [CrossRef]

11. Wu, H.L.; Pan, G.L.; Bai, Y.C.; Wang, H.; Kong, J. Synthesis, structure, antioxidation, and DNA-bindingstudies of a binuclear ytterbium(III) complex with bis(N-salicylidene)-3-oxapentane-1,5-diamine. Res. Chem. Intermed. 2015, 41, 3375-3388. [CrossRef]

12. Wu, H.L.; Bai, Y.C.; Zhang, Y.H.; Pan, G.L.; Kong, J.; Shi, F.; Wang, X.L. Two lanthanide(III) complexes based on the schiff base $N, N$-Bis(salicylidene)-1,5-diamino-3-oxapentane: Synthesis, characterization, DNA-binding properties, and antioxidation. Z. Anorg. Allg. Chem. 2014, 640, 2062-2071. [CrossRef]

13. Wu, H.L.; Bai, Y.C.; Zhang, Y.H.; Li, Z.; Wu, M.C.; Chen, C.Y.; Zhang, J.W. Synthesis, crystal structure, antioxidation and DNA-binding properties of a dinuclear copper(II) complex with bis(N-salicylidene)-3oxapentane-1,5-diamine. J. Coord. Chem. 2014, 67, 3054-3066. [CrossRef]

14. Wu, H.L.; Pan, G.L.; Bai, Y.C.; Zhang, Y.H.; Wang, H.; Shi, F.R.; Wang, X.L.; Kong, J. Study on synthesis, crystal structure, antioxidant and DNA-binding of mono-, di-and poly-nuclear lanthanides complexes with bis (N-salicylidene)-3-oxapentane-1, 5-diamine. J. Photochem. Photobiol. B 2014, 135, 33-43. [CrossRef] [PubMed]

15. Wu, H.L.; Pan, G.L.; Bai, Y.C.; Wang, H.; Kong, J.; Shi, F.R.; Zhang, Y.H.; Wang, X.L. Preparation, structure, DNA-binding properties, and antioxidant activities of a homodinuclear erbium(III) complex with a pentadentate schiff base ligand. J. Chem. Res. 2014, 38, 211-217. [CrossRef]

16. Wu, H.L.; Wang, C.P.; Wang, F.; Peng, H.P.; Zhang, H.; Bai, Y.C. A new manganese(III) complex from bis(5-methylsalicylaldehyde)-3-oxapentane-1,5-diamine: Synthesis, characterization, antioxidant activity and luminescence. J. Chin. Chem. Soc. 2015, 62, 1028-1034. [CrossRef]

17. Song, X.Q.; Liu, P.P.; Wang, C.Y.; Liu, Y.A.; Liu, W.S.; Zhang, M. Three sandwich-type zinc(II)-lanthanide(III) clusters: Structures, luminescence and magnetic properties. RSC Adv. 2017, 7, 22692-22698. [CrossRef]

18. Sun, Y.X.; Wang, L.; Dong, X.Y.; Ren, Z.L.; Meng, W.S. Synthesis, characterization, and crystal structure of a supramolecular Co ${ }^{\mathrm{II}}$ complex containing Salen-type bisoxime. Synth. React. Inorg. Metal-Org. Nano-Metal Chem. 2013, 43, 599-603. [CrossRef] 
19. Sun, Y.X.; Xu, L.; Zhao, T.H.; Liu, S.H.; Dong, X.T. Synthesis and crystal structure of a 3D supramolecular copper(II) complex with 1-(3-\{[(E)-3-bromo-5-chloro-2-hydroxybenzylidene]amino\}phenyl) ethanone oxime. Synth. React. Inorg. Metal-Org. Nano-Metal Chem. 2013, 43, 509-513. [CrossRef]

20. Sun, Y.X.; Zhang, S.T.; Ren, Z.L.; Dong, X.Y.; Wang, L. Synthesis, characterization, and crystal structure of a new supramolecular $\mathrm{Cd}^{\mathrm{II}}$ complex with halogen-substituted Salen-type bisoxime. Synth. React. Inorg. Metal-Org. Nano-Metal Chem. 2013, 43, 995-1000. [CrossRef]

21. Sun, Y.X.; Gao, X.H. Synthesis, characterization, and crystal structure of a new $\mathrm{Cu}^{\mathrm{II}}$ complex with Salen-type ligand. Synth. React. Inorg. Metal-Org. Nano-Metal Chem. 2011, 41, 973-978. [CrossRef]

22. Akine, S.; Taniguchi, T.; Nabeshima, T. Synthesis and characterization of novel ligands 1,2-bis(salicylideneaminooxy)ethanes. Chem. Lett. 2001, 30, 682-683. [CrossRef]

23. Akine, S.; Utsuno, F.; Taniguchi, T.; Nabeshima, T. Dinuclear complexes of the $\mathrm{N}_{2} \mathrm{O}_{2}$ oxime chelate ligand with zinc(II)-lanthanide(III) as a selective sensitization system for $\mathrm{Sm}^{3+}$. Eur. J. Inorg. Chem. 2010, 49, 3143-3152. [CrossRef]

24. Dong, Y.J.; Li, X.L.; Zhang, Y.; Dong, W.K. A highly selective visual and fluorescent sensor for $\mathrm{Pb}^{2+}$ and $\mathrm{Zn}^{2+}$ and crystal structure of $\mathrm{Cu}^{2+}$ complex based-on a novel single-armed Salamo-type bisoxime. Supramol. Chem. 2017, 29, 518-527. [CrossRef]

25. Chen, L.; Dong, W.K.; Zhang, H.; Zhang, Y.; Sun, Y.X. Structural variation and luminescence properties of triand dinuclear $\mathrm{Cu}^{\mathrm{II}}$ and $\mathrm{Zn}{ }^{\mathrm{II}}$ complexes constructed from a naphthalenediol-based bis(Salamo)-type ligand. Cryst. Growth Des. 2017, 17, 3636-3648. [CrossRef]

26. Sun, Y.X.; Liu, L.Z.; Wang, F.; Shang, X.Y.; Chen, L.; Dong, W.K. Structural and hirshfeld surface analyses of a novel hetero-tetranuclear $\mathrm{Cu}^{\mathrm{II}}-\mathrm{Na}^{\mathrm{I}}$ bis(Salamo)-based coordination compound. Crystals 2018, 8, 227. [CrossRef]

27. Zhang, L.W.; Li, X.Y.; Kang, Q.P.; Liu, L.Z.; Ma, J.C.; Dong, W.K. Structures and fluorescent and magnetic behaviors of newly synthesized $\mathrm{Ni}^{\mathrm{II}}$ and $\mathrm{Cu}^{\mathrm{II}}$ coordination compounds. Crystals 2018, 8, 173. [CrossRef]

28. Akine, S.; Kagiyama, S.; Nabeshima, T. Modulation of multimetal complexation behavior of tetraoxime ligand by covalent transformation of olefinic functionalities. Inorg. Chem. 2010, 49, 2141-2152. [CrossRef] [PubMed]

29. Li, L.H.; Dong, W.K.; Zhang, Y.; Akogun, S.F.; Xu, L. Syntheses, structures and catecholase activities of homo- and hetero-trinuclear cobalt(II) complexes constructed from an acyclic naphthalenediol-based bis(Salamo)-type ligand. Appl. Organomet. Chem. 2017, 31, e3818. [CrossRef]

30. Li, X.Y.; Chen, L.; Gao, L.; Zhang, Y.; Akogun, S.F.; Dong, W.K. Syntheses, crystal structures and catalytic activities of two solvent-induced homotrinuclear Co(II) complexes with a naphthalenediol-based bis(Salamo)-type tetraoxime ligand. RSC Adv. 2017, 7, 35905-35916. [CrossRef]

31. Wang, L.; Hao, J.; Zhai, L.X.; Zhang, Y.; Dong, W.K. Synthesis, crystal structure, luminescence, electrochemical and antimicrobial properties of bis(Salamo)-based Co(II) complex. Crystals 2017, 7, 277. [CrossRef]

32. Wang, B.J.; Dong, W.K.; Zhang, Y.; Akogun, S.F. A novel relay-sensor for highly sensitive and selective detection of $\mathrm{Zn}^{2+} / \mathrm{Pic}^{-}$and fluorescence on/off switch response of $\mathrm{H}^{+} / \mathrm{OH}^{-}$. Sens. Actuators B 2017, 247, 254-264. [CrossRef]

33. Dong, W.K.; Li, X.L.; Wang, L.; Zhang, Y.; Ding, Y.J. A new application of Salamo-type bisoximes: As a relay-sensor for $\mathrm{Zn}^{2+} / \mathrm{Cu}^{2+}$ and its novel complexes for successive sensing of $\mathrm{H}^{+} / \mathrm{OH}^{-}$. Sens. Actuators $B$ 2016, 229, 370-378. [CrossRef]

34. Zheng, S.S.; Dong, W.K.; Zhang, Y.; Chen, L.; Ding, Y.J. Four Salamo-type 3d-4f hetero-bimetallic [ $\left.\mathrm{Zn}^{\mathrm{II}} \mathrm{Ln}^{\mathrm{III}}\right]$ complexes: Syntheses, crystal structures, and luminescent and magnetic properties. New J. Chem. 2017, 41, 4966-4973. [CrossRef]

35. Dong, Y.J.; Dong, X.Y.; Dong, W.K.; Zhang, Y.; Zhang, L.S. Three asymmetric Salamo-type copper(II) and cobalt(II) complexes: Syntheses, structures, fluorescent properties. Polyhedron 2017, 123, 305-315. [CrossRef]

36. Dong, X.Y.; Li, X.Y.; Liu, L.Z.; Zhang, H.; Ding, Y.J.; Dong, W.K. Tri- and hexanuclear heterometallic $\mathrm{Ni}(\mathrm{II})-\mathrm{M}(\mathrm{II})(\mathrm{M}=\mathrm{Ca}, \mathrm{Sr}$ and $\mathrm{Ba})$ bis(Salamo)-type complexes: Synthesis, structure and fluorescence properties. RSC Adv. 2017, 7, 48394-48403. [CrossRef]

37. Peng, Y.D.; Li, X.Y.; Kang, Q.P.; An, G.X.; Zhang, Y.; Dong, W.K. Synthesis and fluorescence properties of asymmetrical Salamo-type tetranuclear zinc(II) complex. Crystals 2018, 8, 107. [CrossRef]

38. Li, X.Y.; Kang, Q.P.; Liu, L.Z.; Ma, J.C.; Dong, W.K. Trinuclear Co(II) and mononuclear Ni(II) Salamo-type bisoxime coordination compounds. Crystals 2018, 8, 43. [CrossRef] 
39. Akine, S.; Tadokoro, T.; Nabeshima, T. Oligometallic template strategy for synthesis of a macrocyclic dimer-type octaoxime ligand for its cooperative complexation. Inorg. Chem. 2012, 51, 11478-11486. [CrossRef] [PubMed]

40. Nabeshima, T.; Akine, S.; Ikeda, C.; Yamamura, M. Metallo-supramolecular systems for synergistic functions based on unique arrangement of ligation sites. Chem. Lett. 2010, 39, 10-16. [CrossRef]

41. Akine, S.; Nabeshima, T. Cyclic and acyclic oligo $\left(\mathrm{N}_{2} \mathrm{O}_{2}\right)$ ligands for cooperative multi-metal complexation. Dalton Trans. 2009, 47, 10395-10408. [CrossRef] [PubMed]

42. Dong, X.Y.; Gao, L.; Wang, F.; Zhang, Y.; Dong, W.K. Tri- and mono-nuclear zinc(II) complexes based on halfand mono-Salamo chelating ligands. Crystals 2017, 7, 267. [CrossRef]

43. Dong, W.K.; Ma, J.C.; Zhu, L.C.; Zhang, Y. Nine self-assembled nickel(II)-lanthanide(III) heterometallic complexes constructed from a Salamo-type bisoxime and bearing $\mathrm{N}$ - or O-donor auxiliary ligand: Syntheses, structures and magnetic properties. New J. Chem. 2016, 40, 6998-7010. [CrossRef]

44. Wang, L.; Ma, J.C.; Dong, W.K.; Zhu, L.C.; Zhang, Y. A novel self-assembled nickel(II)-cerium(III) heterotetranuclear dimer constructed from $\mathrm{N}_{2} \mathrm{O}_{2}$-type bisoxime and terephthalic acid: Synthesis, structure and photophysical properties. Z. Anorg. Allg. Chem. 2016, 642, 834-839. [CrossRef]

45. Dong, W.K.; Ma, J.C.; Dong, Y.J.; Zhu, L.C.; Zhang, Y. Di- and tetranuclear heterometallic 3d-4f cobalt(II)-lanthanide(III) complexes derived from a hexadentate bisoxime: Syntheses, structures and magnetic properties. Polyhedron 2016, 115, 228-235. [CrossRef]

46. Hao, J.; Li, L.H.; Zhang, J.T.; Akogun, S.F.; Wang, L.; Dong, W.K. Four homo- and hetero-bismetallic 3d/3d-2s complexes constructed from a naphthalenediol-based acyclic bis(Salamo)-type tetraoxime ligand. Polyhedron 2017, 134, 1-10. [CrossRef]

47. Gao, L.; Liu, C.; Wang, F.; Dong, W.K. Tetra-, penta- and hexa-coordinated transition metal complexes constructed from coumarin-containing $\mathrm{N}_{2} \mathrm{O}_{2}$ ligand. Crystals 2018, 8, 77. [CrossRef]

48. Percy, G.; Thornton, D. Infrared spectra of N-aryl salicylaldimine complexes substituted in both aryl rings. J. Inorg. Nucl. Chem. 1973, 35, 2319-2327. [CrossRef]

49. Dong, W.K.; Ma, J.C.; Zhu, L.C.; Zhang, Y. Self-assembled zinc(II)-lanthanide(III) heteromultinuclear complexes constructed from 3-MeO Salamo ligand: Syntheses, structures and luminescent properties. Cryst. Growth Des. 2016, 16, 6903-6914. [CrossRef]

50. Addison, A.W.; Rao, T.N.; Reedijk, J.; Rijn, J.V.; Verschoor, G.C. Synthesis, structure, and spectroscopic properties of copper(II) compounds containing nitrogen-sulphur donor ligands; the crystal and molecular structure of aqua [1,7-bis( $N$-methylbenzimidazol-20-yl)-2,6-dithiaheptane]copper(II) perchlorate. J. Chem. Soc. Dalton Trans. 1984, 7, 1349-1356. [CrossRef]

51. Liu, Y.A.; Wang, C.Y.; Zhang, M.; Song, X.Q. Structures and magnetic properties of cyclic heterometallic tetranuclear clusters. Polyhedron 2017, 127, 278-286. [CrossRef]

52. Constable, E.C. Expanded ligands-An assembly principle for supramolecular chemistry. Coord. Chem. Rev. 2008, 252, 842-855. [CrossRef]

53. Chai, L.Q.; Li, Y.X.; Chen, L.C.; Zhang, J.Y.; Huang, J.J. Synthesis, X-ray structure, spectroscopic, electrochemical properties and DFT calculation of a bridged dinuclear copper(II) complex. Inorg. Chim. Acta 2016, 444, 193-201. [CrossRef]

54. Sun, Y.X.; Li, C.Y.; Yang, C.J.; Zhao, Y.Y.; Guo, J.Q.; Yu, B. Two Cu(II) complexes with schiff base ligands: Syntheses, crystal structures, spectroscopic properties, and substituent effect. Chin. J. Inorg. Chem. 2016, 32, 327-335.

55. Li, J.; Zhang, H.X.; Chang, J.; Jia, H.R.; Sun, Y.X.; Huang, Y.Q. Solvent-induced unsymmetric Salamo-like trinuclear $\mathrm{Ni}^{\mathrm{II}}$ complexes: Syntheses, crystal structures, fluorescent and magnetic properties. Crystals 2018, 8, 176. [CrossRef]

56. Sun, Y.X.; Zhao, Y.Y.; Li, C.Y.; Yu, B.; Guo, J.Q.; Li, J. Supramolecular cobalt(II) and copper(II) complexes with schiff base ligand: Syntheses, characterizations and crystal structures. Chin. J. Inorg. Chem. 2016, 32, 913-920.

57. Liu, P.P.; Wang, C.Y.; Zhang, M.; Song, X.Q. Pentanuclear sandwich-type Zn ${ }^{\mathrm{II}}$-Ln ${ }^{\mathrm{III}}$ clusters based on a new Salen-like salicylamide ligand: Structure, near-infrared emission and magnetic properties. Polyhedron 2017, 129, 133-140. [CrossRef] 
58. Chen, Y.; Mao, S.S.; Shi, X.K.; Shen, K.S.; Wu, H.L. Synthesis, crystal structure, DNA-binding properties and antioxidant activity of a copper(II) complex with naphthalimide Schiff base. Z. Anorg. Allg. Chem. 2017, 643, 1182-1190. [CrossRef]

59. Shi, X.K.; Mao, S.S.; Shen, K.S.; Wu, H.L.; Tang, X. Synthesis, crystal structure, antioxidation and fluorescence of two lanthanide complexes with a noncyclic polyether Schiff base ligand. J. Coord. Chem. 2017, 70, 2015-2028. [CrossRef]

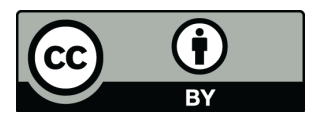

(C) 2018 by the authors. Licensee MDPI, Basel, Switzerland. This article is an open access article distributed under the terms and conditions of the Creative Commons Attribution (CC BY) license (http://creativecommons.org/licenses/by/4.0/). 